\title{
Mikroświat inności dorosłych osób z niepełnosprawnością intelektualną - raport z badań
}

\begin{abstract}
Anna Gutowska, Mikroświat inności dorostych osób z niepetnosprawnościa intelektualnq - raport $z$ badań [The microworld of differentness of adults with intellectual disability: a research report]. Interdyscyplinarne Konteksty Pedagogiki Specjalnej, nr 17, Poznań 2017. Pp. 159-131. Adam Mickiewicz University Press. ISSN 2300-391X

The text is an attempt to present the phenomenon of experiencing otherness by adult people with mental disability. The author presents survey results which are a part of a bigger project researching the microworlds of adults with intellectual disability. In the research, both as the strategy of collecting the research materials and the method of their analysis, the methodology of constructing grounded theory by Kathy Charmaz was used. 14 adults with intellectual disability, attendees of the Community Centre of Self-Help, were researched, as well as 14 attendants (including parents and the centre's employees). The results showed otherness as a specific phenomenon experienced by all the surveyed people with intellectual disability.
\end{abstract}

KEY WORDS: otherness, adult people with intellectual disability

\section{Wstęp}

Celem niniejszego artykułu jest ukazanie zjawiska inności w doświadczeniach dorosłych osób z niepełnosprawnością intelektualną. Stanowi on fragment większego projektu badawczego realizowane- 
go przez autorkę, którego problematyka koncentruje się wokół poznania świata dorosłych osób z niepełnosprawnością intelektualną ${ }^{1}$. Przyjmując, że osoby te, podobnie jak inni dorośli, posiadają określone cechy osobowe, doświadczają i przeżywają różne sytuacje i zdarzenia, podejmują określone role społeczne, są uczestnikami różnorodnych relacji międzyludzkich, mają swój świat wartości i przekonań, badaczka postawiła sobie za cel rozpoznanie i ogląd mikroświatów dorosłych osób z niepełnosprawnością intelektualną. Alfred Schütz twierdzi, że ludzie doświadczają rzeczywistości i podejmują działania $\mathrm{w}$ ramach różnych mikroświatów ${ }^{2}$. Mikroświat rozumiany jako „spójny i względnie samodzielny zespół czy też system, odrębny porządek rzeczywistości" 3 stanowi wysublimowany fragment subiektywnie spostrzeganej rzeczywistości. Autorka, za Ewą Skibińską4, przyjmuje, że mikroświat to świat obecny w doświadczeniu jednego człowieka, który żyje jednocześnie w wielu różnych małych światach (mikroświatach) wyznaczanymi podstawowymi aktywnościami jednostki ${ }^{5}$. Analiza materiału badawczego pozwoliła na wyłonienie kilku mikroświatów ${ }^{6}$, wśród nich mikroświat in-

${ }^{1} \mathrm{~W}$ literaturze przedmiotu obecne są badania dorosłych osób z niepełnosprawnością intelektualną ukazujące ich perspektywę postrzegania siebie/świata. Do kluczowych zaliczyć należy Trudne drogi adaptacji. Wątki emacypacyjne w analizie sytuacji dorostych osób z niepetnosprawnościa intelektualna we wspótczesnym spoteczeństwie polskim Beaty Cytowskiej (2012): B. Cytowska, Trudne drogi adaptacji. Watki emancypacyjne w analizie sytuacji dorostych osób z niepetnosprawnościa intelektualna we wspótczesnym społeczeństwie polskim, Oficyna Wydawnicza „Impuls”, Kraków 2012, czy Żyjąc z zespołem Downa. Narracje biograficzne rodziców, rodzeństwa I dorostych osób z zespołem Downa Agnieszki Żyty, Oficyna Wydawnicza „Impuls”, Kraków 2011.

2 A. Manterys, Wielość rzeczywistości w teoriach socjologicznych, Wydawnictwo Naukowe PWN, Warszawa 1997, s. 24-25.

${ }^{3}$ Cyt. za: A. Manterys, op. cit., s. 19.

${ }^{4}$ E. Skibińska, Mikroświaty kobiet. Relacje autobiograficzne, Wydawnictwo UW, Warszawa 2006, s. 335-336.

${ }^{5}$ Zgodnie ze Słownikiem PWN mikro- to „pierwszy człon wyrazów złożonych wskazujący na bardzo małe rozmiary lub bardzo małą skalę tego, co jest nazwane drugim członem; bardzo mały; www.sip.pwn/slownik/mikro [dostęp: 12.03.2017].

${ }^{6} \mathrm{~W}$ niniejszym projekcie badawczym wyłoniono również inne mikroświaty badanych dorosłych osób z niepełnosprawnością intelektualną m.in. mikroświat 
ności - temat poniższych rozważań. Jest to więc, co należy podkreślić, raport z badań dotyczący jednej wyłonionej przez autorkę kategorii. W tekście wyróżniono kilka części - pierwsza dotyczy metodologii badań, kolejne doświadczania inności przez badane osoby z niepełnosprawnością intelektualną, a ostatnia to próba podsumowania.

\section{Metodologia badań}

Autorka sytuuje swoje rozważania na pograniczu różnych dyscyplin naukowych, w tym głównie andragogiki i pedagogiki specjalnej. Stawia pytania dotyczące tego, jaki jest świat dorosłych $\mathrm{z}$ niepełnosprawnością intelektualną? Jakie elementy składają się na tę rzeczywistość? Czym charakteryzują się owe mikroświaty?

Opracowując swój projekt badawczy, autorka zdecydowała się na przeprowadzenie badania zgodnie $\mathrm{z}$ paradygmatem konstruktywistyczno-interpretatywnym, opierając się na uznaniu podmiotowości i kompetencji badanych osób oraz traktowania ich jako współtwórców procesu badawczego zdolnych do współtworzenia i interpretacji rzeczywistości społecznej. Oddając badanym głos, autorka traktuje ich jako osoby, które mają swój własny sposób widzenia świata, doświadczania i przeżywania i nie są jedynie, jak to bywało w większości badań, obiektami badań, ale ich najkompetentniejszymi podmiotami. Badaczka postępuje zgodnie z myślą Floriana Znanieckiego, który uważał, że rzeczywistość kulturową należy traktować jako świat wartości, a fakty empiryczne należy ujmować tak, jak się jawią jednostkom ludzkim, które ich doświadczają7. Badacz obserwator "nigdy nie będzie miał lepszej wiedzy niż aktorzy, cudzoziemiec nigdy nie pojmie lepiej tubylczej kultury niż tubylcy, ale obserwator i cudzoziemiec mogą mieć inny obraz dzia-

aktywności zawodowej, mikroświat relacji międzyludzkich, mikroświat instytucji, mikroświat cielesności, mikroświat czasu wolnego, mikroświat rodziny.

7 J. Szacki, Historia myśli socjologicznej, Wydawnictwo Naukowe PWN, Warszawa 1986, s. 90-92. 
łania czy kultury niż aktorzy i tubylcy"8. Zakładając, że ludzkie działanie ma charakter emergentny - zachodzi w toku nieustannego konstruowania i nadawania znaczeń ${ }^{9}$ - przyjęto, że zachowanie jednostki jest aktywnie przez nią konstruowane, reinterpretowane i redefiniowane. Szeroko rozumiana aktywność odnosi się także do tworzenia umysłowej reprezentacji samego siebie.

Ponadto paradygmat konstruktywistyczno-interpretatywny pozwala także na elastyczne podejście do badania i ograniczenie przedkonceptualizacji zamierzeń badawczych. Umożliwia to utrzymanie w trakcie badania tzw. kontekstu odkrycia ${ }^{10}$ - przestrzeni na poszukiwanie i odkrywanie nieprzewidzianych wcześniej zjawisk, które wyłaniają się podczas procesu badawczego.

Niniejsze badania wpisują się w jakościową orientację metodologiczną, a badaczka posługuje metodologią konstruktywistycznej teorii ugruntowanej Kathy Charmaz. Wybór ten podyktowany został zarówno specyfiką przedmiotu badań (chęć dogłębnego poznania zjawiska w jego procesualnej postaci), jak i założeniem poznania rzeczywistości w percepcji jej społecznych aktorów. Teoria ugruntowana została wykorzystana zarówno jako strategia zbierania materiału badawczego, jak i metoda jego analizy. W teorii tej dopuszcza się do zbierania danych różne metody typowe dla wszystkich badań jakościowych (m.in. obserwacja uczestnicząca, analiza dokumentacji, wywiady) oraz te odrębne (m.in. analiza tekstu, wywiady jakościowe) ${ }^{11}$. Materiał badawczy w omawianym projekcie badawczym zebrano, wykorzystując wywiad swobodny ukierunkowany ${ }^{12}$, czyli taki sposób prowadzenia rozmowy, który pozwala na dość swo-

8 B. Czarniawska, Nowe techniki badań terenowych: shadowning, [w:] Badania jakościowe. Metody i narzędzia, t. 2, red. D. Jemielniak, Wydawnictwo Naukowe PWN, Warszawa 2012, s. 73.

${ }^{9}$ H. Blumer, Symbolic Interactionism: Perspective and Method, Prentice-Hall, New Jersey 1969, s. 82.

${ }^{10} \mathrm{~K}$. Konecki, Studia z metodologii badań jakościowych: teoria ugruntowana, Wydawnictwo Naukowe PWN, Warszawa 2000, s. 26-27.

${ }^{11}$ K. Charmaz, Teoria ugruntowana. Przewodnik po analizie jakościowej, Wydawnictwo Naukowe PWN, Warszawa 2009.

12 K. Konecki, op. cit. 
bodne aranżowanie sekwencji pytań i, co ważne, dostosowywaniu języka do potrzeb i możliwości badanych. Realizacji przyjętej procedury posłużyły dyspozycje do wywiadu, czyli lista pytań wynikających z potrzeb informacyjnych badaczki. Na tym etapie badań wywiady przeprowadzono zarówno z osobami z niepełnosprawnością intelektualną (łącznie 14 osób w wieku od 29 do 51 lat 8 kobiet i 6 mężczyzn), jak i ich rodzicami/opiekunami (łącznie 8 osób) oraz pracownikami Środowiskowego Domu Samopomocy ${ }^{13}$ (łącznie 6 osób), gdzie badania były realizowane ${ }^{14}$.

Należy także dodać, że ważnym instrumentem badawczym w prowadzeniu niniejszych badan jest tu osoba prowadząca wywiady, czyli sama badaczka. Realizowany projekt badawczy pozwolił na szczególne zbliżenie się badacza do osobistego świata dorosłych osób z niepełnosprawnością intelektualną. Dało to podstawę do podjęcia próby uchwycenia i opisu świata przeżywanego przez badanych.

Uzyskany materiał badawczy poddano procesowi kodowania, najpierw otwartego (przyporządkowanie danym etykiet i ich pogrupowanie), później selektywnego (ukierunkowanie na wyszukiwanie powiązań z kategorią centralną), a na końcu na zogniskowa-

13 Badania realizowane są w jednym ze środowiskowych Domów Samopomocy na terenie województwa łódzkiego. Badani, w tym przede wszystkim pracownicy tej placówki, zastrzegli nieujawnianie dokładnych danych instytucji.

${ }^{14}$ Kryterium doboru badanych był etap życia, tzn. dorosłość (ukończone 18 lat) oraz niepełnosprawność intelektualna. Wszyscy posiadali orzeczenie o stopniu niepełnosprawności. Większość stanowiły osoby z umiarkowanym stopniem niepełnosprawności (10), 3 z lekkim stopniem i 1 z głębokim. Jednak stopień niepełnosprawności nie stanowił w niniejszych badaniach istotnego czynnika ani w aspekcie zbierania danych, ani ich analizy. Zamierzeniem badaczki było zbadanie świata dorosłych osób z niepełnosprawnością intelektualną bez etykietowania opinią czy orzeczeniem o niepełnosprawności i spostrzegania przez pryzmat ograniczeń. W trakcie realizacji badań okazało się, że niektóre informacje ujawnione w wywiadach wymagają uzupełnienia czy szerszego oglądu, co skłoniło badaczkę do włączenia do badań rodziców/opiekunów i pracowników ŚDS. W badaniach uczestniczyło 7 rodziców (2 ojców i 5 matek oraz 1 ciocia - opiekun jednej z badanych) i 6 pracowników - 4 kobiety (kierownik ŚDS, psycholog, 2 terapeutki zajęciowe oraz 2 mężczyzn - terapeuta zajęciowy i pracownik administracyjny). 
nym (uwypuklenie tła interakcyjnego). Analiza pozwoliła na ujawnienie kilku różnych mikroświatów, w których funkcjonują osoby badane. Wśród nich badaczka wyróżniła: mikroświat rodziny, pracy, edukacji, relacji międzyludzkich, czasu wolnego, instytucji i inności. Ich granice nie są stałe i sztywne, pozwalają na wzajemne przenikanie. Należy przy tym dodać, że projekt nie jest ukończony i zgodnie z przyjętą metodologią ewoluuje.

\section{Doświadczanie inności - analiza badań własnych}

W analizowanym materiale badawczym pojawiło się wiele wątków skoncentrowanych wokół inności. W wypowiedziach niemal wszystkich badanych osób z niepełnosprawnością intelektualną znalazło się odniesienie do tego zjawiska. Co ważne, zagadnienie to uwidoczniono także w wypowiedziach rodziców/opiekunów i pracowników/terapeutów. Aby przedstawić syntetyczne fakty, wydarzenia, ale przede wszystkim ich interpretacje, nadawanie znaczeń oraz język jako narzędzie wyrazu i komunikacji badanych, zastosowano strategię typową dla teorii ugruntowanej, czyli zogniskowane kodowanie kategorii. Celem takiego zabiegu jest sortowanie, synteza i organizacja dużej ilości danych ${ }^{15}$, a także ukazanie sposobu, w jaki są one ze sobą powiązane.

Wokół doświadczeń związanych z innością zogniskowano wiele kategorii, które odpowiadały na pytania: czy i dlaczego badani czują się inni? kto i co ma na to wpływ? jakie są wymiary inności? jakie są skutki bycia innym? w jakich sferach życia to się przejawia? To podstawowe pytanie, które zgodnie z myślą Anselma L. Straussa i Juliet M. Corbin ${ }^{16}$, pozwalają badaczowi dokładniej opisać analizowane doświadczenie i pokazać związki pomiędzy kategoriami i podkategoriami oraz na nowo połączyć ze sobą dane.

${ }^{15}$ K. Charmaz, op. cit.

16 A.L. Strauss, J. Corbin, Basics of Qualitative Research: Techniques and Procedures for Developing Grounded Theory, Second edition, Thousand Oaks, Sage 1998. 
Syntetycznie ujęte zjawisko „inności” badanych osób z niepełnosprawnością intelektualną, daje się przedstawić $\mathrm{w}$ postaci następującego schematu:

Schemat 1. Mikroświat inności osób z niepełnosprawnością intelektualną

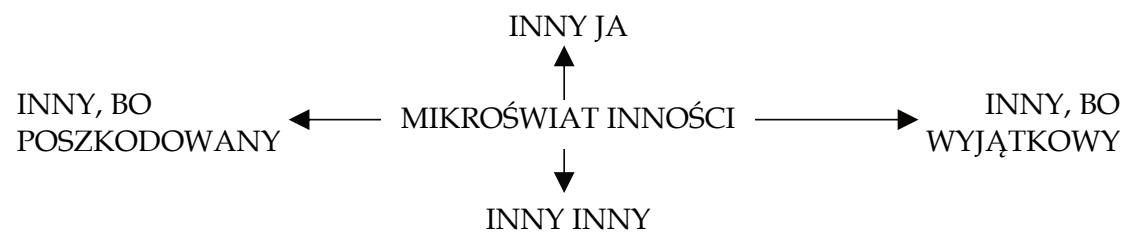

Źródło: opracowanie na podstawie badań własnych

Poniżej dokonano próby opisania każdego z wymienionych obszarów.

\section{Inny ja}

Jak wynika z materiału badawczego, pierwszych doświadczeń inności badane osoby z niepełnosprawnością intelektualną nabywały w szkole. $\mathrm{W}$ żadnym $\mathrm{z}$ wywiadów nie odnotowano odwołań do wcześniejszych etapów życia. W trakcie analizy ujawniono, że wielu badanych wspomina lata szkolne również w kontekście doznawania praktyk, które określono jako doświadczanie inności. Język, jakim posługiwały się badane osoby z niepełnosprawnością intelektualną, opowiadając o tych doświadczeniach, pozwala wnioskować, że większość z nich je rozumiała. Najczęściej wypowiedzi nacechowane był zwrotami bardzo wyrazistymi czy nawet dosadnymi lub wręcz przeciwnie, raczej lapidarnymi.

Poniżej zaprezentowano kilka przykładowych wypowiedzi będących egzemplifikacją wyłonionej kategorii. Badani ujmowali swoje doświadczenia między innymi w kontekście interakcji rówieśniczych: 
Ja w szkole byłem sam, na przerwach czy po, to raczej tak sam chodzitem, nie lubili mnie raczej, takie te dzieciaki niedobre dla mnie byty, chamskie takie, podelce (Marek, 51 lat).

Jak chodziłam do szkoty, to pamiętam, jak inne dzieciaki sie ze mnie śmiały, bo nie umiałam tego czy tamtego albo mnie popychali, pluli i krzyczeli, że głupia, świruska czy Down, płakałam, ale później się przyzwyczaiłam (Iza, 37 lat).

Ja zawsze czułem, że jestem inny od moich kolegów w szkole. Oni spokojniejsi ode mnie byli. Oni patrzyli na mnie $i$ mnie nie rozumieli, ale czasami lubiłem do szkoty przychodzić. W mojej szkole dużo takich pokrzywdzonych byto (Mateusz 37 lat);

jak i wskazywali osoby, fakty, wydarzenia, które utkwiły im w pamięci jako uprzedmiotowiające (budujące inność):

Miałam wychowawczynię taka niemiła, cofnęta mnie. No i miatam wtaśnie komisję, psychologa i jakiegoś tam innego terapeute i mnie cofnęli do specjalnej. Tam też było nie najlepiej, bo wyrośnięta byłam, inna niż pozostali (Irena, 42 lata).

Kiedyś ta pani powiedziała, że jestem najgłupsza z całej klasy $i$ się do nich nie nadaje (Iza 37 lat).

Odniesienia do tego zagadnienia odnaleźć można także w wypowiedziach rodziców badanych osób:

Wie pani, on w szkole byt już inny niż tamte dzieci. Odróżniał się, kolegów nie miat, dokuczali mu bo odmienny, no inny byt i nauczyciele też tak mówili (matka Mateusza).

Moja córka różni się troszkę, no bo niby dorosła, a jednak jak dziecko można powiedzieć. Młodsza córka to już co innego, ma męża, dzieci, no rodzine generalnie, a ta starsza to troszkę inna jest (ojciec Kasi);

oraz pracowników ŚDS:

Większość $z$ nich, to już w szkole przechlapane miała. Stysze przecież czasami, jak wspominaja te trudne dla nich lat, to wyśmiewanie, poni- 
żanie, a kto wie co jeszcze. Wykluczeni byli w większości, bo inni byli, można powiedzieć: nie pasowali (terapeutka).

Omawiane doświadczenia wyniesione ze szkoły mają charakter negatywny. Dotyczą głównie doświadczeń szkolnych, ale i sytuacji nieformalnych, pozaszkolnych. W przypadku tych pierwszych wyraźnie widać, że uczniowie $\mathrm{z}$ niepełnosprawnością intelektualną dostrzegają niechętny, lekceważący, czy wręcz obraźliwy stosunek niektórych nauczycieli i uczniów do nich samych, przy czym dotyczy to zarówno uczniów tzw. normalnych, jak i tych uczących się w szkołach specjalnych.

Warto również zauważyć, że inność, która jest naznaczana przez różne osoby, może przejawiać się zarówno w wyglądzie badanych, jak i ich zachowaniu. $\mathrm{W}$ analizowanych wywiadach ujawniły się takie wypowiedzi, które wskazują, że niektórzy badani zdają sobie sprawę $\mathrm{z}$ tego, że otoczenie zwraca uwagę na pewne zewnętrzne symptomy ich niepełnosprawności. 38-letnia kobieta tak relacjonowała swoje doświadczenia:

Jak ludzie sie na mnie patrza albo takie staruszki patrza: O niepetnosprawna!, to ja się troche boje. No jak się ludzie patrza to ja obracam głowę i nie patrze, nie zwracam uwagi.

Reakcje ludzi peszą ją i wywołują lęk. Na podobne aspekty społecznego odbioru wskazała 27-letnia kobieta, która własne doświadczenia przeniosła na sytuację wszystkich niepełnosprawnych:

Ja wiem, że jak taki normalny człowiek widzi taka osobę, naśmiewa sie $z$ niej, ja to czasami widze, ale też sama wiem jak jest, widze po sobie, jak coś tam komuś się nie podoba (Kasia).

Przyjmując, że swoją tożsamość człowiek buduje w relacji z innymi ludźmi na podstawie ich słów, gestów, spojrzeń, które stanowią swoistą informację zwrotną dla każdej jednostki, można sądzić, że doświadczenia te istotnie wpłynęły na budowanie obrazu świata badanych, w tym na obraz samego siebie. Jeśli, jak chce Martin Bu- 
ber - Ja staje się w zetknięciu z Ty ${ }^{17}$, to przemocowe interakcje, których doświadczali badani mogły w nich ukształtować postawę zależności, słabości i uległości.

W obszarze „Inny ja” można ponadto wyróżnić jeszcze dwa konteksty: odmienność potrzeb i odmienność możliwości badanych osób z niepełnosprawnością intelektualną. W analizowanych wypowiedziach widoczne jest subiektywne odczuwanie tego, co jest potrzebne badanym. Prezentują nieufność, dystans do tego co jest nowe i nie do końca poznane. Uwidoczniona została zmieniona percepcja potrzeb:

Nie umiem korzystać z bankomatu, tak szczerze to nie umiem pobierać pieniędzy, ale nie musze to mi niepotrzebne, siostra weźmie albo mama (Daria, 36 lat).

Komputer to nie dla mnie, po co mi to? No internet to jeszcze może tak, bo to proste, ale inne programy? No po co, żeby coś popsuć? (Mateusz, 37 lat).

Ja mam rentę to nie musze pracować. Te pieniadze sa raz w miesiacu i muszą wystarczyć. No na jedzenie, ubranie, ale jakoś wystarcza (Iza, 37 lat).

Owa odmienność potrzeb, ich ograniczenie ukształtowane zostało przez wcześniejsze doświadczenia i poskutkowało odmiennością rozumianą tu jako inność.

Kolejny kontekst inności ujawniono w perspektywie odmienności możliwości. Uzasadnienia można poszukiwać w następujących wypowiedziach:

To jest dla innych, nie dla mnie (Grzegorz, 34 lata), czy Ja się nie nadaję do tego (Iza, 37 lat),

Jak się jest niepetnosprawnym, tak jak ja, to nie można dużo rzeczy robić (Maria, 29 lat).

${ }_{17}$ M. Buber, J. Doktór, Ja i ty. Wybór pism filozoficznych, Wydawnicwo Pax, Warszawa 1992, s. 45. 
Badane osoby z niepełnosprawnością intelektualną nie czują się wystarczająco silne i kompetentne do podejmowania działań:

O nie! Ja sama to nie mogę mieszkać. Nie umiem dużo rzeczy robić. To znaczy jakieś kanapki, coś tam prostego to tak, ale obiad czy zakupy to mama robi. Nie wiem, czy bym sobie sama poradziła. Nie, raczej nie moge. Nie, ja nie wiem, czy ja bym sobie dawata rade (Maria, 29 lat).

No samodzielnie żyć to jeszcze nie, bo nie wiem jak będzie zopłatami $i$ innymi rzeczami, na razie z rodzicami wole mieszkać. Nie, raczej rady bym nie dat sobie, bo po co? (Grzegorz, 34 lata).

Nie bytabym w stanie wychowywać dziecka, ja nie moge mieć dzieci, bo to nie na moje możliwości. Znaczy urodzić może tak, ale nie wychować. Dlatego, że nie umiałabym mu przekazać wiadomości o życiu, nauczyć bo to ciężka sprawa jest. Jak ja mam problemy z zajmowaniem się teraz bratanica i bratankiem, no nie umiem (Iza, 36 lat).

\section{Inny inny}

Niektóre z badanych osób z niepełnosprawnością intelektualną sytuowały siebie jako osoby inne od innych niepełnosprawnych. Jeden $\mathrm{z}$ mężczyzn wspominał swoje trudne doświadczenia $\mathrm{w}$ pracy. Opowiadał, że w trudnej dla niego sytuacji nie wytrzymał i „wybuchł”. Tłumaczył, że nie rozumiał dlaczego „normalni” pracownicy tak się z niego wyśmiewali, np. z tego, że przychodził do pracy wcześniej niż inni czy że się mylił przy wykonywaniu swoich obowiązków:

Się wkurzyłem, bo wszystko źle było, nawet się kontrolować przestatem, bo się wkurzytem, a ja nie wiem dlaczego się tak nabijali, nawet źle byto, że wcześnie przychodziłem, tym normalnym pracownikom to wszystko przeszkadzało (Tomasz, 32 lata).

Badany nazwał swoich kolegów z pracy normalnymi, mimo że są to osoby z niepełnosprawnością intelektualną - podobnie jak on. 
Podobnie swoje doświadczenia przedstawiała 37-letnia Iza, która uczestniczyła w obozie rehabilitacyjnym z osobami z niepełnosprawnością ruchową:

Tam byłam na rehabilitacji. Już kiedyś też byłam i wtedy poznałam takiego fajnego chłopaka - Adriana, on mieszkał obok z tymi na wózkach, bo tak chodzić nie umiat, a nie z tymi normalnymi, tu gdzie ja.

Taka sytuacja może świadczyć o zjawisku przyjmowania schematów postrzegania osób z niepełnosprawnością (w tym przypad$\mathrm{ku}$ ruchową). Społeczne powielanie wizerunku niepełnosprawnych ruchowo wśród sprawnej części społeczeństwa może powodować internalizację oceny otoczenia społecznego wobec jednostek z inną niepełnosprawnością oraz różnicujące postrzeganie osób z niepełnosprawnością ruchową.

Wydaje się, że odczuwanie zarówno własnej, jak i cudzej inności było i nadal jest jednym z najpowszechniejszych doświadczeń emocjonalnych człowieka. Podział na My i Oni, to podział bez którego trudno wyobrazić sobie funkcjonowanie w świecie. Naturalna potrzeba poszukiwania podobieństw i różnic odgrywa istotną rolę w budowaniu tożsamości.

\section{Inny, bo wyjątkowy}

Inny, bo wyjątkowy, to rodzaj inności osiągniętej. Myślą przewodnią jest tu zaangażowanie w aktywność, w której badani czują się dobrze, odnoszą sukcesy i są doceniani. Charakterystyczna jest tu wypowiedź Dawida, 32-latka:

Ja mam talent, nie jestem taki jak inni. Nie wszyscy tak umieja śpiewać, a ja ładnie śpiewam i często występuje na scenie. Lubię śpiewać, bardzo. I dostaje nagrody na festiwalach, bo ja mam talent.

Szczególnym uzdolnieniem Dawida jest jego muzykalność. To ta sfera jego funkcjonowania, w której osiąga sukcesy. Dawid jest 
solistą i można powiedzieć liderem zespołu muzycznego działającego w Środowiskowym Domu Samopomocy. Koledzy i pracownicy ŚDS-u nazywają go gwiazdą i „zwierzęciem estradowym”. Terapeutka, która prowadzi zespół uważa, że:

Dawid wielu rzeczy nie umie, nie potrafi robić z powodu swoich deficytów, ale mimo to jest naprawdę wyjątkowy, bo potrafi pięknie śpiewać. Ma stuch i naprawde dobry głos, tadna barwe i dobra skale. Do tego jeszcze można powiedzieć, że potrafi zinterpretować piosenkę, on naprawdę rozumie o czym śpiewa, rozumie muzykę. Wczuwa się $w$ nia, prezentuje emocje, wchodzi w to cata osoba. No to jest wyjątkowe, bo nie każdy przecież tak potrafi. On, gdyby byt inny, czyli petnosprawny i przyjęli go do jakiegoś talent show, to może nawet by wygrat (pracowniczka ośrodka).

Ciekawa jest też kolejna wypowiedź tej terapeutki:

Dawid podczas występów jest innym człowiekiem. Wchodzi na scenę, bierze mikrofon i diametralnie się zmienia. Śpiewa i się zmienia, naprawdę. Można powiedzieć, że przestaje być upośledzony. On zastuguje na miano gwiazdy, na scenie jest gwiazda bez dwóch zdań (pracowniczka ośrodka).

Kolejnym przykładem zaangażowania w aktywność związaną ze szczególnym talentem jest Mateusz. Ten 37-letni mężczyzna wykazuje uzdolnienia plastyczne. Można powiedzieć, że malowanie obrazów jest głównym zajęciem tego badanego:

Ja tak lubie malować, że moge to robić cały czas. $W$ domu też maluję. Mam farby, pędzle $i$ siedze, $i$ maluje, bo ja lubię. Mam bardzo dużo obrazów $i$ te wszystkie, co tu wisza, to też sa moje i tam na korytarzu i przy wejściu, no na wystawy też dają i mam sukcesy.

Jeszcze innym obszarem inności osiąganej jest sport. Przykładem osoby szczególnie uzdolnionej w tej sferze jest 34-letni Piotr. Badany wykazuje w tym zakresie zdolności rozwinięte na wysokim 
poziomie. Aktualnie uprawia cztery dyscypliny sportowe, wszystkie z sukcesami:

Ja bardzo lubie jeździć na zawody sportowe. Te puchary tam na dole to moje, no nie wszystkie, ale dużo. To jest bardzo fajne. Przyjeżḋaja $z$ innych ośrodków, miejsc różnych $i$ się spotykamy, ćwiczymy i sq zawody [...]. Ja jestem bardzo dobry, mnie chwala, inni nie sa tacy dobrzy, ale Tomek też ze mna biega.

Terapeuta wspierający Piotra mówi:

Piotrek to naprawde utalentowany chłopak. Jest silny $i$ zacięty, chętnie ćwiczy, trenuje. On jest wyjatkowy, bo rzadko jest zniechęcony czy zmęczony tak jak inni (pracownik ośrodka).

Efekt inności jako wyjątkowości dostrzegany jest zatem zarówno przez same osoby z niepełnosprawnością intelektualną, jak i otoczenie. Skutkuje to zmianą pozycji osoby w najbliższym środowisku, jej wyższym statusem w grupie, ale też poczuciem przewagi. Inność osiągana to poszukiwanie własnej tożsamości i wykorzystywanie jej do kreowania siebie. To inność akceptowana, a wręcz pożądana.

\section{Inny, bo pokrzywdzony}

Wypowiedzi badanych osób z niepełnosprawnością intelektualną ujawniły także szczególne ujęcie inności, a mianowicie spostrzeganie siebie jako osoby pokrzywdzonej przez los, nieszczęśliwej, dotkniętej chorobą, cierpiącej. Jedna z narratorek, opowiadając o swoich doświadczeniach podczas wizyty w przychodni lekarskiej, przypomniała słowa starszej kobiety oczekującej z nią w kolejce do lekarza:

Ta pani do mnie powiedziała: oj, bo ty taka bidulka jesteś, no ja wiem, że ja taka biedna jestem, inni nie musza się tak męczyć jak ja. No i mia- 
ła rację, bo po co sa osoby niepetnosprawne? Czemu Bóg tak zrobit? No nie wiadomo (Iza, 37 lat).

Inny badany, 37-letni Mateusz, w sposób przejmujący opowiadał o swoich doświadczeniach:

Czasami chciałbym się nigdy nie urodzić, bo po co? Nie musiałbym się wstydzić [...] i cierpieć. Kto by się śmiat wtedy? Jak bym byt zdrowy.

Wśród wypowiedzi znalazły się również takie, które ukazują utożsamianie przez badanych swojej niepełnosprawności z chorobą:

Ta moja niepetnosprawność to choroba jest, nie tak jak u innych ludzi u mnie jest, bo jestem chora, upośledzona (Daria, 36 lat).

Jak się choruje, to tak jest, chory ma problemy, jak ja. Mam na to rente (Iza, 37 lat).

Moje życie jest bardzo smutne. Nie chce już pamiętać o tym [...], chce normalnie żyć, jak zdrowy i normalny. Tak żeby być w domu, jeść obiad, chodzić do sklepu, rano poleżeć, nie od razu do ośrodka. Lubię tu być, ale lepiej normalnie żyć i być zdrowym (Mateusz, 37 lat);

co znajduje potwierdzenie także $w$ wypowiedziach rodziców badanych osób z niepełnosprawnością intelektualną:

Ja się martwię, bo ona przez tę swoja niepetnosprawność jest inna, biedna taka, bardziej wrażliwa i naiwna, no taka bezradna często. No los ja i nas trochę skrzywdzit. Czasami się zastanawiam dlaczego ona taka poszkodowana (matka Marii).

Ja to sobie nieraz nad jej losem popłacze, bo wie Pani biedna ona jest (matka Darii).

Taki rodzaj inności może wynikać z potrzeby zapobiegania stygmatyzacji. Osoby z niepełnosprawnością intelektualną są znacznie silniej naznaczone piętnem niż osoby chore. Przeświadczenie o zminimalizowania izolacji społecznej i marginalizacji powoduje przesunięcie punktu ciężkości z niepełnosprawności intelektualnej 
na stan choroby. Widoczne jest także pielęgnowanie strat wynikających z deficytów i często wyuczonej bezradności. Taki stan może prowadzić do zaniechania podejmowania różnych aktywności i dawać poczucie bezpieczeństwa zarówno osobom z niepełnosprawnością intelektualną, jak i ich opiekunom. Sytuacja osoby, której inność jest utożsamiana z poszkodowaniem, może wydawać się łatwiejsza do zaakceptowania społecznie.

\section{Zakończenie}

Podsumowując, należy zauważyć, że analizowany materiał badawczy pozwala na dostrzeżenie wielowymiarowości zjawiska inności. Inność jawi się tu jako zjawisko względne i wzajemne, ale też uniwersalne $\mathrm{z}$ uwagi na swój zasięg i możliwości interpretacji. Jak zauważał Erving Goffman, role społeczne Innych i normalsów nie są rolami danymi raz na zawsze. Inny może zatem w określonych sytuacjach, w pewnym kontekście być normalsem i odwrotnie ${ }^{18}$.

Widoczne jest także zjawisko wchodzenia i trwania w roli Innego. Badane osoby $\mathrm{z}$ niepełnosprawnością intelektualną nie tylko czują się inne, ale też jako inne są traktowane. Przejawia się to m.in. w niepodejmowaniu niektórych ról społecznych, zwolnieniu od pewnych obowiązków czy oczekiwaniu pomocy. Od osób z niepełnosprawnością intelektualną oczekuje się poprawnych, niekonfliktowych zachowań i podporządkowania, nie zaś rozwoju i aktywnego udziału w życiu społecznym. Po części to społeczeństwo naznacza innością i marginalizuje osoby $\mathrm{z}$ niepełnosprawnością intelektualną, a po części oni sami wycofują się ze sceny społecznej. Jak pisze Beata Cytowska „osoby odbiegające od preferowanego wzorca gotowe są zinternalizować ideologie grupowe, które lokują je na niskich pozycjach w hierarchii społecznej, wyrzekając się niejednokrotnie własnych przekonań i wartości"19. Badane osoby

${ }^{18}$ E. Goffman, Piętno. Historia zranionej tożsamości, Wydawnictwo GWP, Gdańsk 2007.

19 B. Cytowska, op. cit., s. 122-123. 
z niepełnosprawnością intelektualną w większości mają świadomość własnej odmienności, gorszej pozycji i przypisywanych jej negatywnych właściwości i ocen. Społeczne zaszufladkowanie powoduje przyswojenie sobie niższego statusu, ograniczenie osobistego rozwoju i przystosowanie się do niepełnosprawności ${ }^{20}$. Inność doświadczeń osób z niepełnosprawnością intelektualną sprzyja izolacji społecznej, jest źródłem budowania i pogłębiania alienacji.

Zjawisko inności jest ściśle związane z uprzedzeniami, stereotypami $^{21}$, piętnowaniem ${ }^{22}$ i dyskryminacją ${ }^{23}$. Uprzedzenie to ocena (często tendencyjna) grupy czy jednostki, która najczęściej oparta jest na wyobrażonych jej właściwościach ${ }^{24}$. Zawierają w sobie zarówno komponent przekonań, jak i emocji i gotowości do działania. Simone de Beauvoir napisała, że „pojęcie Innego jest tak odwieczne, jak sama świadomość. Nawet w najprymitywniejszych społeczeństwach, najstarszych mitologiach odnajdujemy pojęcie dwoistości Tożsamego i Innego"25. Rzeczywistość, w której żyjemy, zmusza do spotkań z Innym, jednak problem tych spotkań pozostaje otwarty i wciąż aktualny. W dużej mierze to od nas zależy jakie te spotkania będą i jaki skutek przyniosą. Obecnie realizuje się wiele programów aktywizujących i integrujących, mających na celu wyjście z marginesu społecznego osób z niepełnosprawnością intelektualną. Są one przedmiotem troski i stwarza im się jak najlepsze warunki w placówkach, w których mają wieść niefrasobliwe życie. Ale czy takie

${ }^{20}$ M. Skura, Ja - inny. Relacje społeczne osób z niepetnosprwnościa, Wydawnictwo UW, Warszawa 2016, s. 8.

$21 \mathrm{O}$ „obowiązywalności” stereotypu dziecka uposledzonego umysłowo pisała Elżbieta Zakrzewska-Manterys w publikacji Dziecko upośledzone - nieuchronność stereotypów z 2003 r.

22 Jedną z najbardziej znanych pozycji dotyczących procesu piętnowania jest Piętno. Historia zranionej tożsamości Ervinga Goffmana po raz pierwszy wydana w $1963 \mathrm{r}$.

${ }^{23} \mathrm{O}$ dyskryminacji pisał m.in. Stanisław Kowalik (np. Psychospołeczne podstawyrehabilitacji osób niepetnosprawnych (1999); Pomiędzy dyskryminacją a integracja osób niepetnosprawnych (2001).

${ }^{24}$ www.bezuprzedzen.org/dyskryminacja/index.php?\&tekst [dostęp: 12.03.2017].

25 S. de Beauvoir, Druga pteć, Wydawnictwo Czarna Owca, Warszawa 2003, s. 27. 
postępowanie wobec dorosłych osób - dostosowanie do ich funkcji intelektualnych, a nie etapu życia i dojrzałości fizycznej, społecznej nie należy do przejawów dyskryminacji?

Warto w tym miejscu także zauważyć, że analiza materiału badawczego doprowadziła badaczkę do takiego punktu, w którym należało dokonać namysłu nad obecnymi w literaturze przedmiotu charakterystykami czy opisami osób z niepełnosprawnością intelektualną. Tradycyjne, tworzone na podstawie klinicznych badań głównie w obszarze psychologii klinicznej, odnoszą się przede wszystkim do deficytów i przedstawiane jako nieodwracalne i rzutujące na całą osobowość jednostki ${ }^{26}$. Wydają się więc nie do końca przystawać do danych będących wynikiem badań interpretatywnych. W perspektywie zebranych danych wydają się być wąskie, nieuwzględniające wszystkich sfer funkcjonowania, a więc niewystarczające. W pewnym sensie można powiedzieć, że budują obraz inności osób z niepełnosprawnością intelektualną.

Kończąc, należy zauważyć, że niniejsze badania pokazują, że inność jest istotnym elementem składającym się na rzeczywistość badanych osób z niepełnosprawnością intelektualną. Bezzasadnym byłoby ujednolicenie ich doświadczeń i problemów, ale analiza materiału badawczego ujawniła obecność zjawiska inności w świecie niemal wszystkich badanych. Ma ono jednak różny wymiar i konsekwencje. Może być źródłem zarówno dyskryminacji, jak i czynnikiem chroniącym, pomagającym (np. chroni przed podejmowaniem wyzwań, zadań czy ról społecznych, ale także chroni poprzez eksponowanie nadspodziewanych osiągnięć).

Trzeba zatem uznać, że skoro inność jest fenomenem doświadczanym przez niemal wszystkie badane osoby z niepełnosprawnością intelektualną, to wymaga dalszej eksploracji czyniącej jego oglądalność możliwą w różnych perspektywach i panoramicznej, szerokiej refleksji. Konieczna jest także teoretyzacja wyników badań, której próbę autorka podejmie, zgodnie z przyjęta metodologią, na zakończenie całego projektu badawczego.

26 Por. np. J. Kostrzewski - 1981, H. Borzyszkowska - 1985, R. Kościelak - 1989, J. Lausch-Żuk - 1987, Ż. Stelter - 2009. 


\section{Bibliografia}

Beauvoir de S., Druga płeć, Wydawnictwo Czarna Owca, Warszawa 2003.

Blumer H., Symbolic Interactionism: Perspective and Method, Prentice-Hall, New Jersey 1969.

Buber M., Ja i ty. Wybór pism filozoficznych, Wydawnictwo Pax, Warszawa 1992.

Charmaz K., Teoria ugruntowana. Przewodnik po analizie jakościowej, Wydawnictwo Naukowe PWN, Warszawa 2009.

Cytowska B., Trudne drogi adaptacji. Wattki emancypacyjne w analizie sytuacji dorostych osób z niepełnosprawnościa intelektualna we wspótczesnym społeczeństwie polskim, Oficyna Wydawnicza „Impuls”, Kraków 2012.

Czarniawska B., Nowe techniki badań terenowych: shadowning, [w:] Badania jakościowe. Metody i narzędzia, t. 2, red. D. Jemielniak, Wydawnictwo Naukowe PWN, Warszawa 2012.

Goffman E., Piętno. Historia zranionej tożsamości, Wydawnictwo GWP, Gdańsk 2007.

Konecki K., Studia z metodologii badań jakościowych: teoria ugruntowana, Wydawnictwo Naukowe PWN, Warszawa 2000.

Kowalik S., Psychospołeczne podstawy rehabilitacji osób niepetnosprawnych, Wydawnictwo BPS, Katowice 1999.

Kowalik S., Pomiędzy dyskryminacją a integracją osób niepetnosprawnych, [w:] Wspomaganie rozwoju. Psychostymulacja i psychokorekcja. T. 3, red. B. Kaja, Wydawnictwo AB, Bydgoszcz 2001.

Manterys A., Wielość rzeczywistości w teoriach socjologicznych, Wydawnictwo Naukowe PWN, Warszawa 1997.

Skibińska E., Mikroświaty kobiet. Relacje autobiograficzne, Wydawnictwo UW, Warszawa 2006.

Strauss A.L., Corbin J., Basics of Qualitative Research: Techniques and Procedures

for Developing Grounded Theory, Second edition, Thousand Oaks, Sage 1998.

Skura M., Ja - inny. Relacje społeczne osób z niepetnosprawnością, Wydawnictwo UW, Warszawa 2016.

Szacki J., Historia myśli socjologicznej, Wydawnictwo Naukowe PWN, Warszawa 1986.

www.bezuprzedzen.org/dyskryminacja/index.php?\&tekst [dostęp 12.03.2017].

www.wsip.pwn/slownik/mikro [dostęp: 12.03.1027].

Zakrzewska-Manterys E., Dziecko upośledzone - nieuchronność stereotypów, [w:] Niepetnosprawność intelektualna a style życia, red. A. Gustavsson, J. Tossebro, E. Zakrzewska-Manterys, Wydawnictwo PAN, Warszawa 2003. 